\title{
Critical Assessment of Banking Institutions in South Africa
}

\author{
Bakam Fotso, ${ }^{*}$ E.I Edoun \\ University of Johannesburg, South Africa \\ genischou@gmail.com, *eiedoun@uj.ac.za
}

\begin{abstract}
Banks play an important role in a country's economy through investments, deposits and withdrawals. Many banking products are sold to clients to meet their financial needs and obligations. Their performances are therefore very critical in supporting socio economic development. Financial institutions still facing challenges linked to the lack of financial previsions through the use of financial tool that allows preventing financial distress. Banks are not always well-managed because managers lack capacity and the sound knowledge in dealing effectively with the analysis of risk and return and decision-making. The current study highlights and gives orientations on key performance indicators that bank can use to manage their financial conditions in advance in a sustainable manner. The major objective of this research is to critically assess the South African banks performance using Financial Ratio Analysis (FRA)and descriptive statistics through comparative financial statement analysis form 2010 to 2013 between " the big four" South African banks. In using correlational analysis, the study aim to establish the link between exogenous and endogenous variables of bank performance. The results showed that FirstRand bank was the best achiever with a higher level of performance following by Standard bank, then Absa and Nedbank. Furthermore, it appears that there is a strong relationship between bank performance and bank size because the volume of assets represents the bigger source of bank incomes. This study opens door to further study including both large and small banks and a comparative analysis between two research methods. The paper is divided into five major sections.
\end{abstract}

Keywords: South Africa, Banks, performance, economic development, financial ratios, decision making

\section{Introduction}

Banking institutions play a pivotal role on the overall growth of an economic system of each and every country around the world. Measuring and evaluating their performance is very important in determining the key performance indicators in advance. Such indicators allow adjusting financial variables and therefore preventing any sudden decline, failure or crisis that can impact the financial system. Understanding internal factors or conditions of financial institutions and the relationship with foreign economies enables to point out missing or shortcoming on inefficient approaches in order to perform better performances. South African banking institutions comprises monetary policy handled by the reserve bank, locally and foreign controlled banks and mutual banks (SARB, 2014). The advent of democracy in South Africa in 1994 through the government of national unity (GNU) changed the landscape of the South African economy. A number of laws were voted for commercial, investment and other banks types thereafter to improve the banking sector so that it becomes more productive and competitive in the global economy. The South African Reserve Bank (SARB) is the institution that is responsible for the financial system stability through regulations and supervision of banks' activities internally and externally (SARB, 2014). Currently, the South African banking sector includes 17 registered banks, 3 mutual banks, 2 co-operative banks, 14 local branches of foreign banks, 43 foreign banks with approved local representative offices as published by SARB (2014). But South Africa has an oligopolistic market competition as confirmed by Mlambo and Ncube (2011). Oligopoly can be defined as a competitive market where there are fewer sellers of the same product on the market. In South Africa only four large commercial banks that include First National Bank, Standard Bank, Nedbank and ABSA represent more than $86 \%$ of the total industry assets (SARB, 2014). Despite this low degree of competition, the overall banking industry growth continues to improve regarding the financial stabilization and the country's GDP growth per capita.

Observations showed that banks are not always aware on real time of the declining situation of their financial position for many reasons. However, it happens that bank managers miss focus on the key performance indicators and the efficient management of resources that lead to financial issues. This study is important in that, it contributes in advising on the improvement of the financial performance of the four large South African Commercial banks. Such improvements are done through financial analysis of significant ratios related to profitability, liquidity, credit and capital performance and through correlation between bank size 
and bank performances. The results will certainly assist bank managers in decision-making process to achieve greater results in a sustainable manner following a preventive approach.

\section{Literature Review}

Authors have different point of view in defining or explaining key performance indicator of banks. For some, it about internal indicator such as efficiency and ownership while for others it related to external impacts such as market conditions, belonging to economic group and supervisory system. Bank efficiency has been at the center of debates related to their performance for service delivery. Ncube (2009) and Baten and Begum (2012) inferred that bank efficiency depends mostly on products units resources through cost, profit and technical efficiency analysis. Kristo (2012) used the stochastic frontier analysis techniques to establish the relationship between bank efficiency and bank size. He found that the efficiency of banking system is related to the size of bank market share through economic group integration. Somehow, there are standalone bank that perform well and better than banks belonging to specific economic group. Adewoye and Omoregie (2013) demonstrated that increasing bank size through technological innovation contribute in improving their cost efficiency. According to Zago and Dongili (2011), credit quality management especially based on loans issues must first be considered to increase bank efficiency. Some researchers believed that the statistic method used to do the research tells more about the efficiency of the research findings.

Bodla and Bajaj (2010) who emphasized only on measuring bank efficiency using Data Envelopment Analysis known as DEA whereas Nguyen et al. (2013) went further with the measurement of bank super-efficiency using the Slacks Based Model (SBM) under the estimation of variable returns to scale (VRS). They concluded that the larger the bank, the less guarantee the super efficiency scores in comparison with small banks. In this regard Shamsuddin and Xiang (2012) also assumed that although big banks have mastered a certain level of cost efficiency, they are still facing a lower level of technical efficiency compared to small banks. Bank efficiency analysis uses many techniques and approaches that require certain operating business condition like producing in optimal scale to be appropriates highlighted by Oluitan (2014). He found that efficiency implies excessive low costs that finally lead to the inefficiency. Bank efficiency is related to cost cutting and economy of scale that challenge performance improvement in a competitive environment.

Bank productivity emphasizes on bank financial performance using the CAMEL rating (Capital Adequacy, Assets Quality, Management Efficiency, Earning Quality, Liquidity and Sensitivity to Market Risk) compared to the other financial ratios. The study conducted by Jamil and Sahar (2013) focused on evaluating banks performance through comparative analysis between Indian banks using CAMELS rating and sensitivity to Market Risk approach. They concluded that the easy integration of banks in the emerging and globalized market improved their performance. Among all financial ratios, Van der Westhuizen (2014) and Monea (2011) confirmed that Return on Equity (ROE) and Return on Assets (ROA) known as profitability ratios as well as operating ratios such as Net Interest Margin (NIM) and cost to income ratio (C/I) are the most important ratios that accurately tell about bank performances. But observations showed that all ratios have a significant scope in evaluating bank performances.

Moreover, for some reasons, one ratio can be accurate in explaining performances of certain banks but not in all banks. That is why performance analysis needs to take into account the industry and the macro environment impact. Al-Karim and Alam (2013) confirmed that bank performance evaluation have to be done according to the internal, market and economic environment. In another extent, Market Value Added (MVA) and Economic Value Added (EVA) helps in improving bank' share value hence their best internal and external performance (Oberholdzer and Van der Westhuisen, 2010). Kumbirai and Webb (2010) emphasized on profitability, liquidity and credit ratios to compare financial performance of South African banks before and after crisis.They found that South African banks remained in a sound position as they benefited from limited exposure to foreign currency debt. Bank management requires a certain amount of capital as another key determinant of bank performance. Huang et al. (2012) emphasized that leverage and Capital adequacy ratio both tell about capital performance of a bank. Based on the literature, studies around bank performance topic showed that financial ratios inform accurately about all aspects of bank performance. However, analysis needs to consider the use of different accounting practices in each bank. Many internal factors such as political, market and economic conditions influence the performance of banks as well as external factors like 
international standard regulations that have a profound impact on bank management. This study also talks about bank size, bank ownership and bank supervisory system that affect financial performance of South African Banks.

Many authors such as Kristo (2012), Al-Karim and Alam (2013) and Adewoye and Omoregie (2013) took into account the impact of bank size through economic group integration and technological innovation on bank performance. They also found that volume of assets, market shares; number of employees (Ncube, 2009) is the best proxies to estimate the size of the bank. In order to increase their size and further improving their cost efficiencies and therefore their performances, banks can look for interbank merging rather than be independent (Huang et al., 2012; Paradi et al., 2010) and product development through technological innovations through new branches, new products and services. Banks can be owned by private people and/or by the government. But usually, profitability efficiently increases with foreign ownership especially during post-privatization compared to nationalized banks (Narjess et al., 2005). However, Jagwani (2012) believed that public sector banks remain more efficient than private and foreign banks because of the continuous resources availability. Despite the difference in ownership structure, technical efficiency is relatively the same in private and public bank sector regarding the nonperforming loans (NPL) as confirmed by Chaffai and Lassoued (2013).

Bank supervisory framework improves the management of the banking performances through policies and regulations. However, Maimbo (2002) found that a lack of enforcement and supervisory forbearance undermine the key role played by those institutions and increase the risk of bank failure. In South Africa, the banking supervisory system protected banks against market change and negative impact of the crisis (Van der Westhuisen, 2013; Erasmus and Makina, 2014). Banks supervisory department of the South Africa Reserve Bank also defines bank legislation and international standards to be followed by all banks. Beyond those factors, observations showed that skilled personnel, technology innovation and other stakeholders are the building blocks of banking performances. Moreover, the sound regulation and supervision system comprise bank supervision (Basel capital accord), financial surveillance and exchange controls and national payment system (SARB, 2014). In developed countries, financial development is related to the powerful economic growth in all sectors. All factors influencing financial performance are known and efficiently managed than in the developing countries. The quality of the governance takes into account the need to outperform both in public and private management of banks. Banking sector is predominated by holding companies that perform well than independent banks (Huang et al., 2012). This is evident in countries such as United States of America, United Kingdomand China.

In developing countries, many bank managers don't know the key performance indicators to focus on in order to increase bank productivity. In Taiwan, financial institutions are dominated by subordinated banks under financial holding company than independent banks (Huang et al., 2012). The easy integration of banks in India emerging market (economic transitions) increased their bank performance as asserted by Jamil and Sahar (2013). In South Africa context, banks performance analysis is influenced by oligopolistic nature of market condition (Mlambo and Ncube, 2011) because only four banks are known as big banks out of 17 registered banks. Therefore, the low rate of competition undermines the efficiency of the banking industry. However, technological innovations related to the economic liberalization led to the improvement of internal and foreign banking transactions and their improvement (Van der Westhuisen, 2013). Based on the abovementioned, many studies put forward that efficiency and/or productivity characterize and increase bank performances. This study focus on bank productivity using financial ratios analysis to explain financial performance of South African financial institutions. Many studies conducted around bank performances in South Africa, focused on the period around the financial crisis that occurred in 2007(Van Heerden and Heymans, 2013). However, the study conducted by Erasmus and Makina (2014) showed that the effect of financial crisis on the South African banking system was minimal because of the sound supervisory system (Van der Westhuisen, 2013) and the low exposure to foreign currency debt (Kumbirai and Webb, 2010). This implies that considering the financial crisis event on research related to South African bank performance is not significant. Compared to the previous studies, the present study period is going from 2010 to 2013 and focuses on endogenous factors because they are more accurate for measuring bank performances as asserted by Tesfaye (2014). This study also adds capital performance as another determinant because Bentum (2012) 
highlighted its influence on risks and leverage. Furthermore, trend analysis is done not only per sampling period but will integrate comparative analysis per bank over the sampling period.

\section{Methodology}

The selected banks namely Absa, FirstRand, Nedbank and Standard chartered Bank are all registered at Johannesburg Stock Exchange (JSE). The chosen sample is accurate and appropriate as it represents over $86 \%$ of the South African banks population as stipulated by Salkind (2012) and published by SARB (2014). The study has used data collected from the various annual reports of the selected commercial banks that include Absa, FirstRand, Nedbank and Standard chartered bank as published on the South African Reserve bank's website (www.sarb.co.za) as well as data published on each bank website from 2010 to 2013. This study follows a quantitative research approach because it uses "quantitative analysis techniques such as graphs, charts and statistics allow us to explore, present, describe and examine relationships and trends within our data" as stated by Saunders and Cornett (2011). The study uses descriptive statistics and correlational analysis in order to establish the relationship between bank performance variables (Salkind, 2012). Correlational research techniques is appropriate in this context because the study seeks to establish if there is a relationship between level of performance and other variables such as bank size quantifiable through the volume of assets. Hypothesis will be tested by means of variables from 2010 to 2013 that will allow to criteria as if P-value $<\mathrm{B}$, reject the null hypothesis; if P-value $>\mathrm{B}$, accept the null hypothesis. $\mathrm{B}$ defined as being level of significance.

Statistical analysis of data in this study will be done using Microsoft Excel software. It remains our best software for calculations, charts and different illustrations for all the above-mentioned. The Performance measurement tools used in this study is the Financial Ratios Analysis because it informs about bank' operations and financial condition over time, across banks and across the banking industry. Moreover, it reveals bank strengths and weaknesses as highlighted by Kumbirai and Webb (2010) and Brigham and Daves (2010). Financial Ratios Analysis uses standardized numbers to easily compare bank performance in the industry as well as around the world. Variables use in the study is displayed in the table below:

Table 1: Variables use in the study

\begin{tabular}{llll}
\hline Variables & Ratios & Description & Average Range \\
\hline Profitability & ROA & Return on Assets & $>1$ \\
Performance & ROE & Return on Equity & $15-20 \%$ \\
& C/I & Cost to Income & $<50 \%$ \\
Liquidity & NLTA & Net Loans to Total Assets & $80 \%$ \\
Performance & NLDST & Net Loans to Deposit and Borrowing & $70-80 \%$ \\
Credit quality & IL & Impairment Loss & $<1$ \\
Performance & NPL & Non-Performing Loan over the total of loans & $<5$ \\
Capital & LR & Leverage Ratio or total liabilities to total assets & $<8 \%$ \\
Performance & CAD & Capital Adequacy Ratio or Capital to Risk weighted assets & $>10 \%$ \\
Size & & Volume of Assets & \\
\hline SOlu
\end{tabular}

Source: http://www.investopedia.com/ask/answers/

\section{Results and discussions of key findings}

Profitability Trend: Profit maximization is the main objective of any business to assure long-term viability. Profitability performance is the key measure of any business performance. In this study, profitability is measured in terms of Return on Assets (ROA), Return on Equity (ROE) and Cost-to-Income (C/I). Profitability performance is outlined for the sample period and per selected South African banks (FirstRand, Standard, Absa and Nedbank). The summary statistics of variables shows the mean and the standard deviation.

Profitability on the sample period: The summary statistics of profitability ratios is shown in the table 2 below. Figure 1 below shows an overall increasing profitability trend from 2010 to 2013 despite a slightly drop of efficiency ratio in 2013. ROA and ROE increased continuously during the sample period due to the profit 
earning increase. Net interest incomes on loans and advances to customers and non-interest revenue all increase income as well as the profit. This improvement shows the return on different bank' investment. Efficiency ratio decreased from 57\% in 2010 to $48 \%$ in 2013 because of the increase of incomes. Therefore, South African banks showed better performance from 2010 to 2013.

Table 2: Summary statistics of variables from 2010 to 2013

\begin{tabular}{llllllll}
\hline Ratios & Years & ABSA & FIRSTRAND & NEDBANK & STANDARD & Mean & SD \\
\hline \multirow{4}{*}{ ROA } & 2010 & 0.94 & 1.3 & 0.65 & 0.97 & 0.965 & 0.265895 \\
& 2011 & 1.13 & 1.5 & 0.87 & 1.12 & 1.155 & 0.259551 \\
& 2012 & 0.96 & 1.73 & 1 & 1.23 & 1.23 & 0.35393 \\
& 2013 & 1.08 & 1.87 & 1.06 & 1.3 & 1.3275 & 0.377657 \\
& 2010 & 14.2 & 17.7 & 8.3 & 12.5 & 13.175 & 3.905018 \\
ROE & 2011 & 15.8 & 18.7 & 10.9 & 14.3 & 14.925 & 3.245895 \\
& 2012 & 12.28 & 20.7 & 11.8 & 14.2 & 14.745 & 4.103182 \\
& 2013 & 15.25 & 22.2 & 12.2 & 14.1 & 15.9375 & 4.360309 \\
& 2010 & 56.7 & 53.3 & 56.3 & 61.7 & 57 & 3.481379 \\
C/I & 2011 & 55.6 & 53.3 & 56.8 & 58.8 & 56.125 & 2.299819 \\
& 2012 & 52.7 & 53.4 & 56.3 & 58.7 & 55.275 & 2.764507 \\
& 2013 & 55.9 & 51.9 & 56.6 & 28.5 & 48.225 & 13.31199 \\
\hline
\end{tabular}

Source: ABSA, FirstRand Bank, Nedbank, Standard bank websites: various annual reports.

Figure 1: Profitability trend from 2010 to 2013

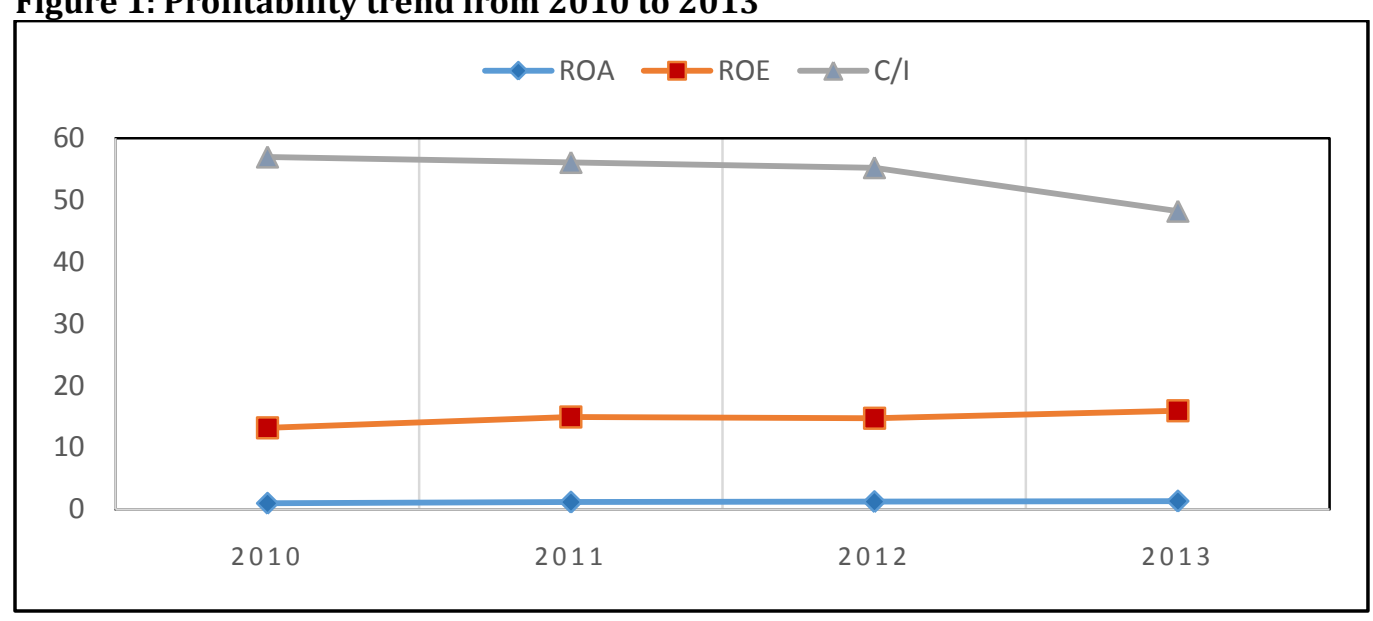

Profitability per South African Bank: The summary statistics of profitability ratios is shown in the table 3 below.

Table 3: Summary statistics of variables from 2010 to 2013 per Bank

\begin{tabular}{llllllll}
\hline Banks & Years & $\mathbf{2 0 1 0}$ & $\mathbf{2 0 1 1}$ & $\mathbf{2 0 1 2}$ & $\mathbf{2 0 1 3}$ & Mean & SD \\
\hline \multirow{3}{*}{ ABSA } & ROA & 0.94 & 1.13 & 0.96 & 1.08 & 1.0275 & 0.09215 \\
& ROE & 14.2 & 15.8 & 12.28 & 15.25 & 14.3825 & 1.55087 \\
& C/I & 56.7 & 55.6 & 52.7 & 55.9 & 55.225 & 1.746186 \\
\multirow{2}{*}{ FIRSTRAND } & ROA & 1.3 & 1.5 & 1.73 & 1.87 & 1.6 & 0.25152 \\
& ROE & 17.7 & 18.7 & 20.7 & 22.2 & 19.825 & 2.01556 \\
& C/I & 53.3 & 53.3 & 53.4 & 51.9 & 52.975 & 0.71821 \\
NEDBANK & ROA & 0.65 & 0.87 & 1 & 1.06 & 0.895 & 0.181567 \\
& ROE & 8.3 & 10.9 & 11.8 & 12.2 & 10.8 & 1.75309 \\
\hline
\end{tabular}




\begin{tabular}{llllllll}
\hline & C/I & 56.3 & 56.8 & 56.3 & 56.6 & 56.5 & 0.24494 \\
& ROA & 0.97 & 1.12 & 1.23 & 1.3 & 1.15 & 0.14387 \\
STANDARD & ROE & 12.5 & 14.3 & 14.2 & 14.1 & 13.78 & 0.8539 \\
& C/I & 61.7 & 58.8 & 58.7 & 28.5 & 51.93 & 15.6785 \\
\hline
\end{tabular}

Source: ABSA, FirstRand Bank, Nedbank, Standard bank websites: various annual reports.

Figure 2: Profitability trend per bank from 2010 to 2013

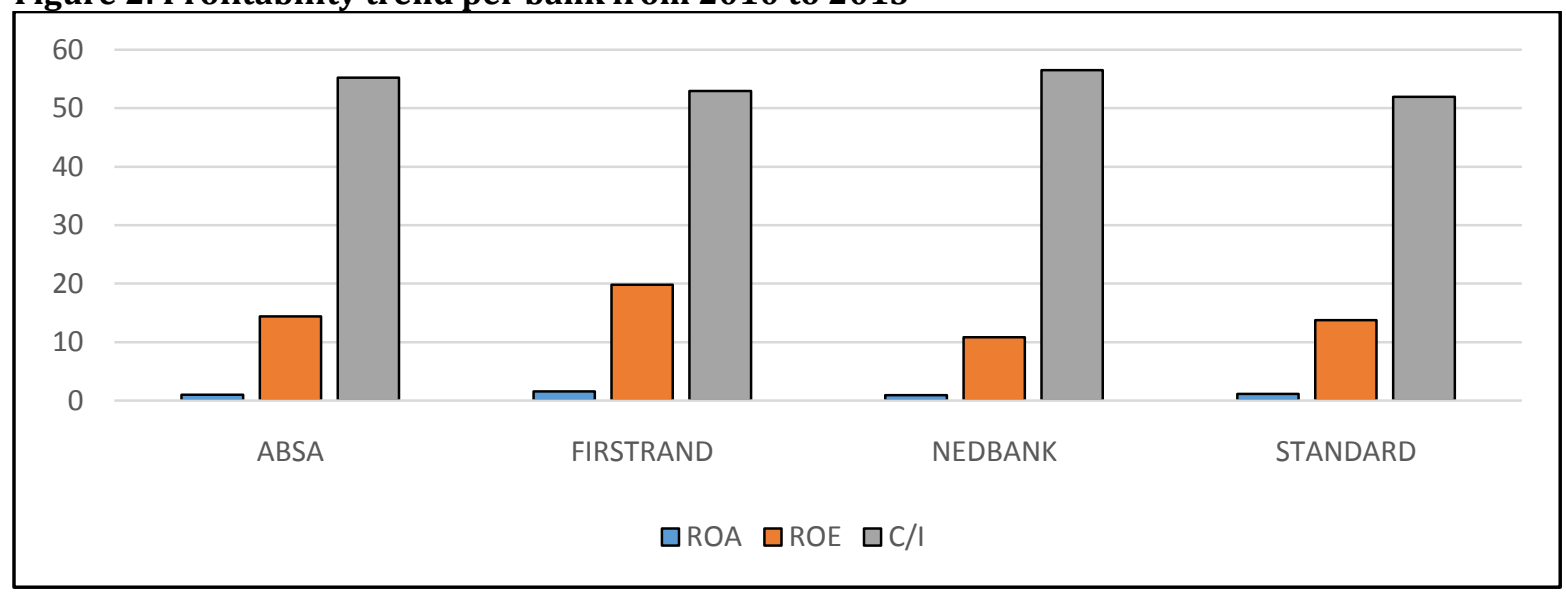

Figure 2 shows that during the sample period, FirstRand bank was the best achiever because it has the higher ROA about $1.6 \%$, ROE of $19 \%$ and a lower cost to income ratio about 52\%. The second achiever is Standard Bank with the lowest efficiency ratio about $51 \%$ and the better return on equity and assets. The third achiever is Absa and the fourth is Nedbank. Throughout the sample period all banks were efficiently using their assets to make a profit because the ROA mean was always above 1 except the case of Nedbank. Only First Rank and Absa could meet the standard average between 15-20\% ranges which means that they had an attractive level on investment equity. Unlike the other banks, Nedbank realized the best efficiency ratio by meeting 56\% when the average must be 50\%. Although Nedbank has a lower level of ROA and ROE, it has a good control of the overall overhead on its revenue.

Liquidity Trend: The uncertainty and the risk of banking operations brought banks to control their liquidity level to prevent bankruptcy and failure. The present study emphasizes on net loans to total assets (NLTA) and net loans to deposits and short-term borrowing (NLDST) as liquidity ratios. These ratios don't assess liquidity itself in first place but they measure illiquidity that also informs about liquidity as pointed out by Kumbirai and Webb (2010).

Liquidity on the sample period: The summary statistics of liquidity ratios is shown in the table 4 below.

Table 4: Summary statistics of variables from 2010 to 2013

\begin{tabular}{llllllll}
\hline Ratios & Years & ABSA & FIRSTRAND & NEDBANK & STANDARD & Mean & SD \\
\hline \multirow{4}{*}{ NLTA } & 2010 & 76.7 & 51.44 & 81.78 & 53.34 & 65.815 & 15.65919 \\
& 2011 & 74.3 & 66.56 & 80.37 & 53.67 & 68.725 & 11.51849 \\
& 2012 & 73.78 & 68.13 & 80.6 & 52.55 & 68.765 & 11.95194 \\
& 2013 & 74.89 & 63.93 & 81 & 53.08 & 68.225 & 12.32127 \\
& 2010 & 90.7 & 85.67 & 95.99 & 90 & 90.59 & 4.231887 \\
NLDST & 2011 & 87 & 84.03 & 95.43 & 91.39 & 89.4625 & 4.996741 \\
& 2012 & 85 & 86.51 & 95.84 & 87.5 & 88.7125 & 4.861587 \\
& 2013 & 86.7 & 85.93 & 96.67 & 89.95 & 89.8125 & 4.892364 \\
\hline
\end{tabular}

Source: ABSA, FirstRand Bank, Nedbank, Standard bank websites: various annual reports 
The above liquidity trend shows that net loans to total asset (NLTA) increased by $2.9 \%$ from 65.8 in 2010 to 68.7 in 2011 before decreasing in 2013 to68.2\%. Such decrease is the fruit of the increase of net loans due to the increase of impairment loans loss and the increase of total assets from other banks' operations. The decrease trend of this NLTA ratio implies the increase of banks liquidity. The higher level of this ratio shows that assets are mostly formed by loans which are not secure for a bank. Net loans to total deposit and shortterm borrowings (NLDST) decreased slightly from 2010 with $90 \%$ to about $89 \%$ in 2013. The low this ratio, the larger the amount of deposit from customers and short term funding. However, the lower rate is also related to the monetary policy on lending requirements. The decrease of the trend implies an increase of liquid assets. Banks must lend a reasonable percentage of its deposits or borrowed funds to be liquid all the time in case of sudden customers' withdrawals.

Figure 3: Liquidity trend from 2010 to 2013

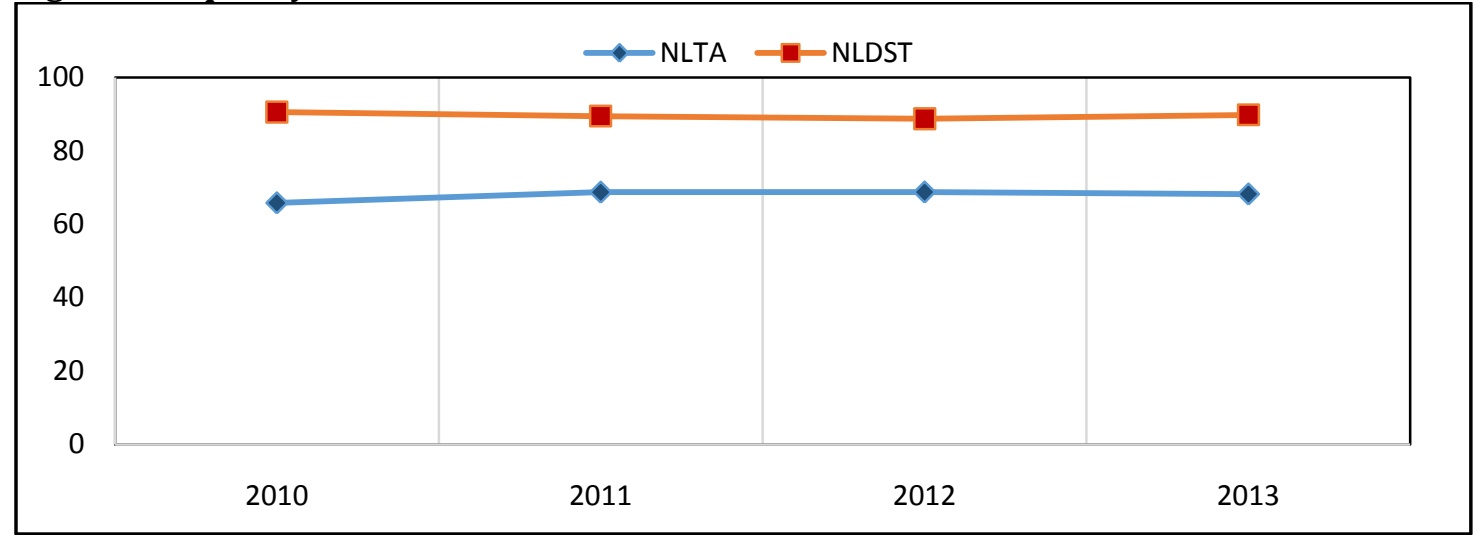

Liquidity per South African Bank: The summary statistics of liquidity ratios is shown in the table 5 below.

Table 5: Summary statistics of variables from 2010 to 2013 per Bank

\begin{tabular}{llllllll}
\hline Banks & Years & $\mathbf{2 0 1 0}$ & $\mathbf{2 0 1 1}$ & $\mathbf{2 0 1 2}$ & $\mathbf{2 0 1 3}$ & Mean & SD \\
\hline \multirow{2}{*}{ ABSA } & NLTA & 76.7 & 74.3 & 73.78 & 74.89 & 74.9175 & 1.271911 \\
& NLDST & 90.7 & 87 & 85 & 86.7 & 87.35 & 2.400694 \\
FIRSTRAND & NLTA & 51.44 & 66.56 & 68.13 & 63.93 & 62.515 & 7.583933 \\
& NLDST & 85.67 & 84.03 & 86.51 & 85.93 & 85.535 & 1.062999 \\
\multirow{2}{*}{ NEDBANK } & NLTA & 81.78 & 80.37 & 80.6 & 81 & 80.9375 & 0.619052 \\
& NLDST & 95.99 & 95.43 & 95.84 & 96.67 & 95.9825 & 0.515841 \\
\multirow{2}{*}{ STANDARD } & NLTA & 53.34 & 53.67 & 52.55 & 53.08 & 53.16 & 0.472934 \\
& NLDST & 90 & 91.39 & 87.5 & 89.95 & 89.711 & 1.617426 \\
\hline
\end{tabular}

Source: ABSA, FirstRand Bank, Nedbank, Standard bank websites: various annual reports. 
Figure 4: Liquidity trend per bank from 2010 to 2013

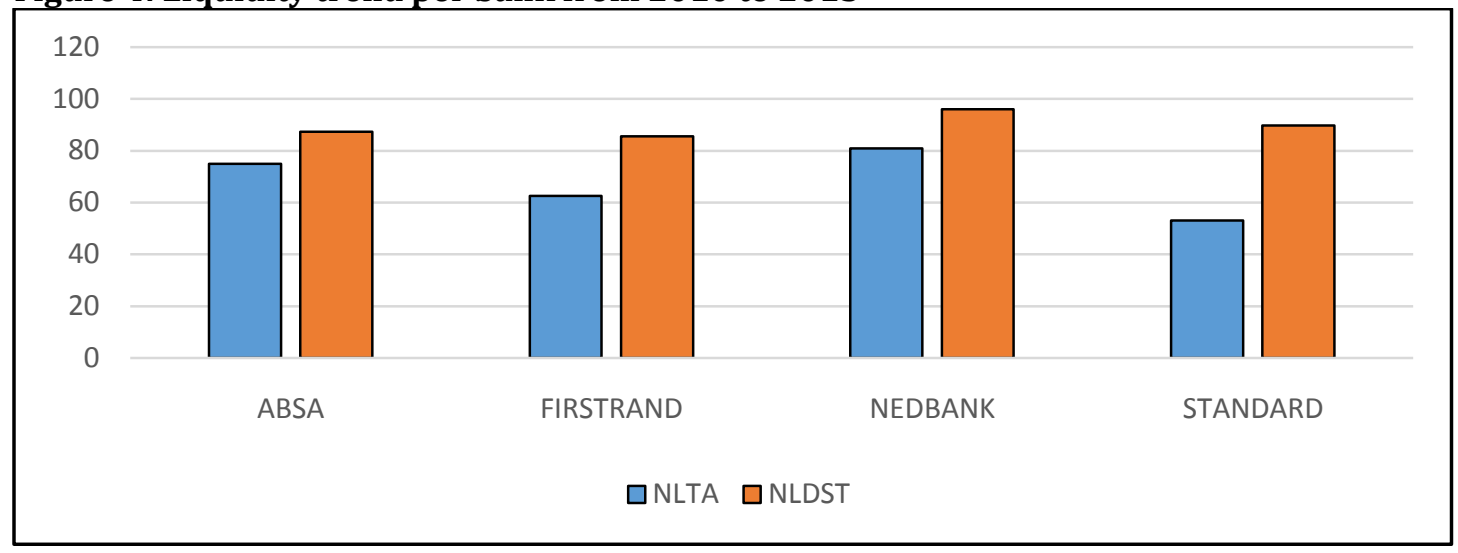

The higher the NLTA, the less liquid the bank is. Nedbank is the less liquid after ABSA compare to Standard Bank and Fist Rank Bank. The higher NLTA ratio indicates that a higher volume of Nedbank's assets is tied up as loan. The average of NLDST ratio is more than $85 \%$ which is a little high. This is not safe for those banks because they can be vulnerable to any sudden adverse changes in the deposit base.

With regards to the above-mentioned analysis about liquidity ratios, the liquidity trend shows that the four South African commercial banks were performing well from 2010 to 2013. The comparative analysis shows that FirstRand had a first higher liquidity performance, Standard bank the second, Absa the third and Nedbank the fourth. Although banks' liquidity is an indicator of performance, there is a minimum requirement of liquid assets indicated by the South African Reserve Bank that all banks follow.

Credit Trend: The intermediation function of banks leads them to face risky operations related to their asset portfolio. Therefore, banks need to closely examine these risks by controlling credit performance ratios. The present study stands on impairment loss (IL) ratio and Non-performing ratio (NPL) as credit ratios.

Credit ratios on the sample period: The summary statistics of credit ratios is shown in the table 5 below.

Table 5: Summary statistics of variables from 2010 to 2013 per Bank

\begin{tabular}{llllllll}
\hline & Years & ABSA & FIRSTRAND & NEDBANK & STANDARD & Mean & SD \\
\hline \multirow{4}{*}{ IL } & 2010 & 1.12 & 1.3 & 1.3 & 1.03 & 1.1875 & 0.135 \\
& 2011 & 1 & 0.82 & 1.1 & 0.87 & 0.9475 & 0.126853 \\
& 2012 & 1.6 & 1 & 1 & 1 & 1.15 & 0.3 \\
& 2013 & 1.14 & 0.96 & 0.97 & 0.96 & 1.0075 & 0.088459 \\
\multirow{4}{*}{ NPL } & 2010 & 7.5 & 5 & 7.8 & 6.1 & 6.6 & 1.298717 \\
& 2011 & 6.9 & 4.19 & 7.3 & 4.1 & 5.6225 & 1.714261 \\
& 2012 & 6.5 & 3.5 & 7 & 3.8 & 5.2 & 1.805547 \\
& 2013 & 5.76 & 3.8 & 6.81 & 3.3 & 4.9175 & 1.648886 \\
\hline
\end{tabular}

Source: ABSA, FirstRand Bank, Nedbank, Standard bank websites: various annual reports. 
Figure 5: Credit trend from 2010 to 2013

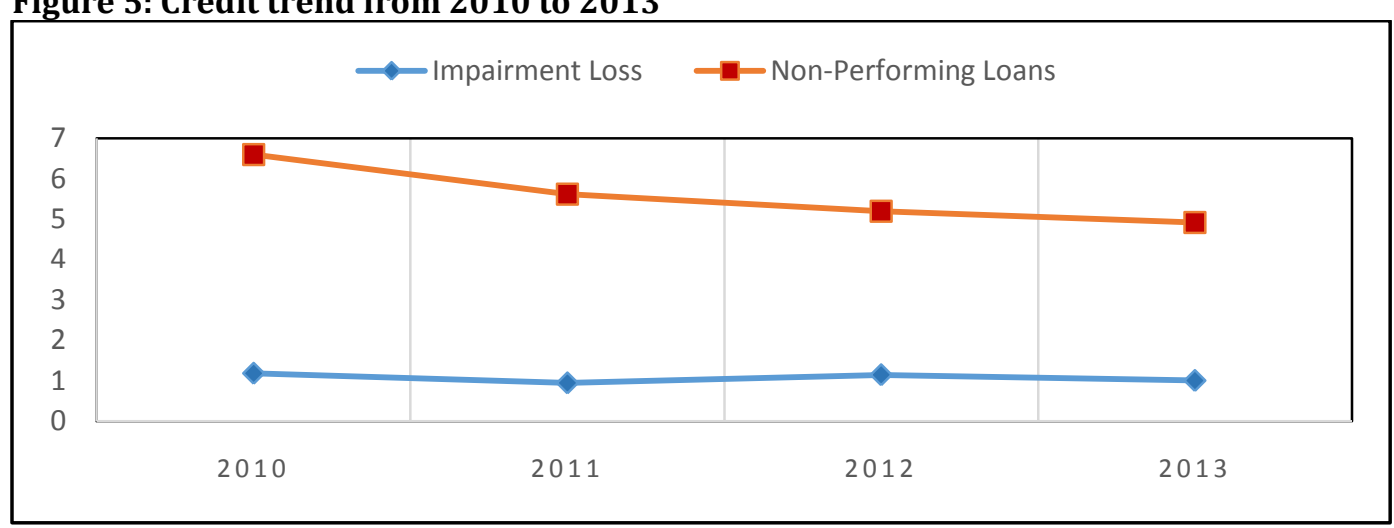

Figure 5 shows a downward trend of the Non-performing loans from 2010 to 2013 . The decrease is due to the continued growth in loans and advances to customers and also the decrease of non-performing loans. This implies a good improvement of credit performance of these South African banks compared to the period from 2005 to 2007 as studied by Mabwe and Webb (2010). Impairment loss ratio is relatively weak because most customers are not defaulted and most assets portfolio (loans) is not too risky. But the slight increase in 2012 was largely due to the deterioration in business and unsecured portfolios. The lower amount of default loans explains the decrease of provision for loan loss during the same period. The higher the non-performing loan ratio and charge-off percentages, the higher the provision for loan losses should probably be. Consequently, net interest incomes will decrease as well as profit earnings.

Credit ratios per South African Bank: The summary statistics of profitability ratios is shown in the table 7 below.

Table 7: Summary statistics of variables from 2010 to 2013 per Bank

\begin{tabular}{llllllll}
\hline Banks & Ratios & $\mathbf{2 0 1 0}$ & $\mathbf{2 0 1 1}$ & $\mathbf{2 0 1 2}$ & $\mathbf{2 0 1 3}$ & Mean & SD \\
\hline \multirow{2}{*}{ ABSA } & IL & 1.12 & 1 & 1.6 & 1.14 & 1.215 & 0.264008 \\
& NPL & 7.5 & 6.9 & 6.5 & 5.76 & 6.665 & 0.73 \\
\multirow{2}{*}{ FIRSTRAND } & IL & 1.3 & 0.82 & 1 & 0.96 & 1.02 & 0.20199 \\
& NPL & 5 & 4.19 & 3.5 & 3.8 & 4.1225 & 0.649635 \\
\multirow{2}{*}{ NEDBANK } & IL & 1.3 & 1.1 & 1 & 0.97 & 1.09 & 0.149081 \\
& NPL & 7.8 & 7.3 & 7 & 6.81 & 7.225 & 0.431692 \\
\multirow{2}{*}{ STANDARD } & IL & 1.03 & 0.87 & 1 & 0.96 & 0.965 & 0.069522 \\
& NPL & 6.1 & 4.1 & 3.8 & 3.3 & 4.325 & 1.228481 \\
\hline
\end{tabular}

Source: ABSA, FirstRand Bank, Nedbank, Standard bank websites: various annual reports.

\section{Figure 6: Credit trend from per bank from 2010 to 2013}

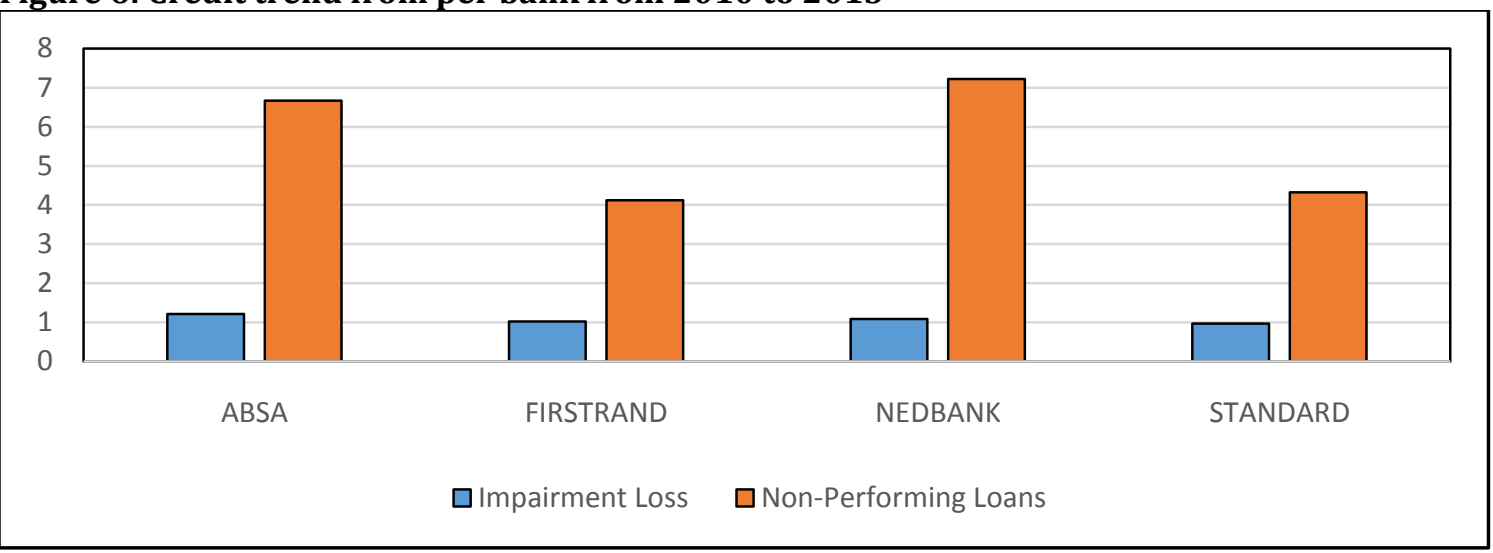


The overall average of NPL is good and shows that the percentage of non-performing loan by the total of outstanding loans in the bank portfolio is very low. This means that borrowers make effort to pay back before 90 days. Regarding the above-mentioned comments, figure 6shows that FirstRand had the lowest impairment loss ratio, followed by Standard bank, Absa and then Nedbank. Nedbank and Absa had the highest level of non-performing loans compared to the other banks. Finally, FirstRand had a best credit performance, followed by Standard bank, Absa and then Nedbank.

Capital Trend: The present study focuses on leverage ratio (LR) and the Capital adequacy ratio (CAD) as capital ratios.

Capital ratios on the sample period: The summary statistics of profitability ratios is shown in the table 8 below.

Table 8: Summary statistics of variables from 2010 to 2013

\begin{tabular}{llllllll}
\hline Ratios & Years & ABSA & FIRSTRAND & NEDBANK & STANDARD & Mean & SD \\
\hline \multirow{4}{*}{ LR } & 2010 & 6.6 & 7.34 & 7.83 & 7.75 & 7.38 & 0.562554 \\
& 2011 & 7.2 & 8.02 & 7.98 & 7.8 & 7.75 & 0.378946 \\
& 2012 & 7.8 & 8.36 & 8.5 & 8.7 & 8.34 & 0.386092 \\
& 2013 & 7.08 & 8.42 & 8.7 & 9.2 & 8.35 & 0.906054 \\
& 2010 & 14.8 & 14.3 & 14.9 & 15.3 & 14.825 & 0.411299 \\
CAD & 2011 & 14.5 & 16.5 & 15.8 & 14.3 & 15.275 & 1.05317 \\
& 2012 & 15.2 & 14.6 & 15.3 & 14.3 & 14.85 & 0.479583 \\
& 2013 & 15.5 & 15 & 14.5 & 16.2 & 15.3 & 0.725718 \\
\hline
\end{tabular}

Source: ABSA, FirstRand Bank, Nedbank, Standard bank websites: various annual reports.

Figure 7: Capital trend from 2010 to 2013

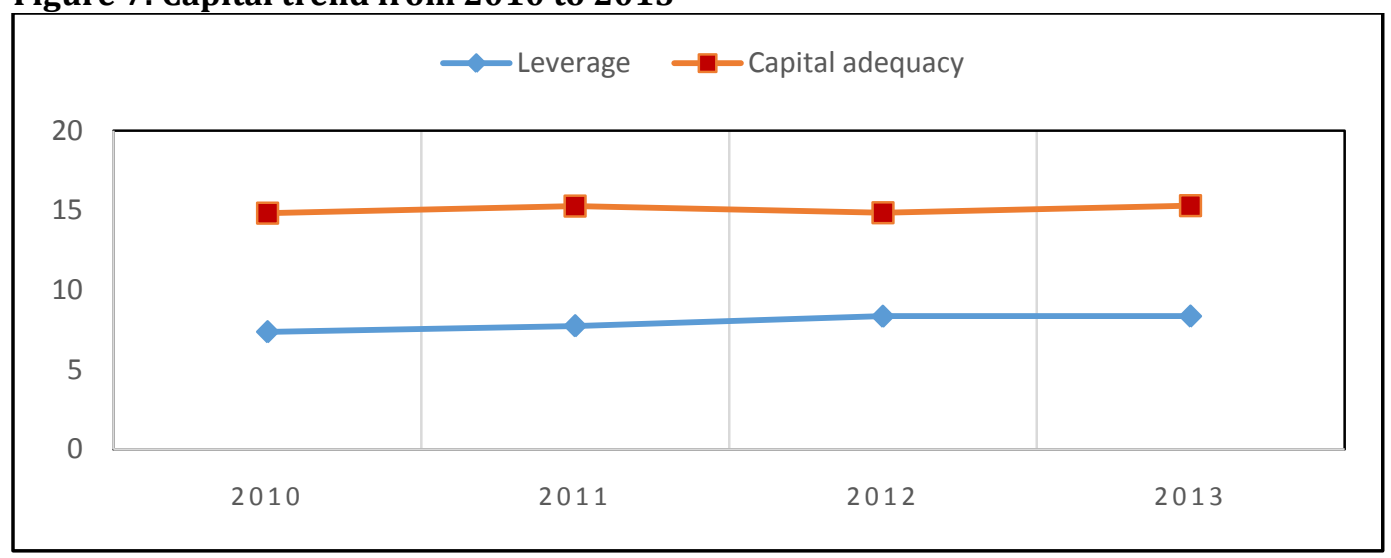

The Capital trend presented in figure 6 shows an upward trend of leverage ratio from 2010 to 2013. As a percentage of total assets to equity, the increase of leverage ratio is mostly caused by the increase of Equity. Customers' ability to repay debt encourages shareholders to invest more equity in order to increase revenues. The slight decrease in 2012 is due to the decrease of loans reserves. The four banks kept a good capital amount since the overall mean is more than $14 \%$ above the minimum capital requirements.

Capital ratios per South African Bank: The summary statistics of capital ratios is shown in the table 9 below. 
Table 9: Summary statistics of variables from 2010 to 2013 per Bank

\begin{tabular}{llllllll}
\hline Banks & Ratios & $\mathbf{2 0 1 0}$ & $\mathbf{2 0 1 1}$ & $\mathbf{2 0 1 2}$ & $\mathbf{2 0 1 3}$ & Mean & SD \\
\hline \multirow{2}{*}{ ABSA } & LR & 6.6 & 7.2 & 7.8 & 7.08 & 7.17 & 0.493559 \\
& CAD & 14.8 & 14.5 & 15.2 & 15.5 & 15 & 0.439697 \\
\multirow{2}{*}{ FIRSTRAND } & LR & 7.34 & 8.02 & 8.36 & 8.42 & 8.035 & 0.495681 \\
& CAD & 14.3 & 16.5 & 14.6 & 15 & 15.1 & 0.976388 \\
NEDBANK & LR & 7.83 & 7.98 & 8.5 & 8.7 & 8.2525 & 0.414035 \\
& CAD & 14.9 & 15.8 & 15.3 & 14.5 & 15.125 & 0.556028 \\
STANDARD & LR & 7.75 & 7.8 & 8.7 & 9.2 & 8.3625 & 0.708725 \\
& CAD & 15.3 & 14.3 & 14.3 & 16.2 & 15.025 & 0.914239 \\
\hline
\end{tabular}

Source: ABSA, FirstRand Bank, Nedbank, Standard bank websites: various annual reports.

Figure 8 below shows that all four South African banks are well-capitalized because the Capital Adequacy Ratio (CAD) ratio is more than $10 \%$ and the leverage ratio less than $10 \%$. They then have enough capital to sustain operating business like potential losses and withdrawals.

Figure 8: Capital trend per bank from 2010 to 2013

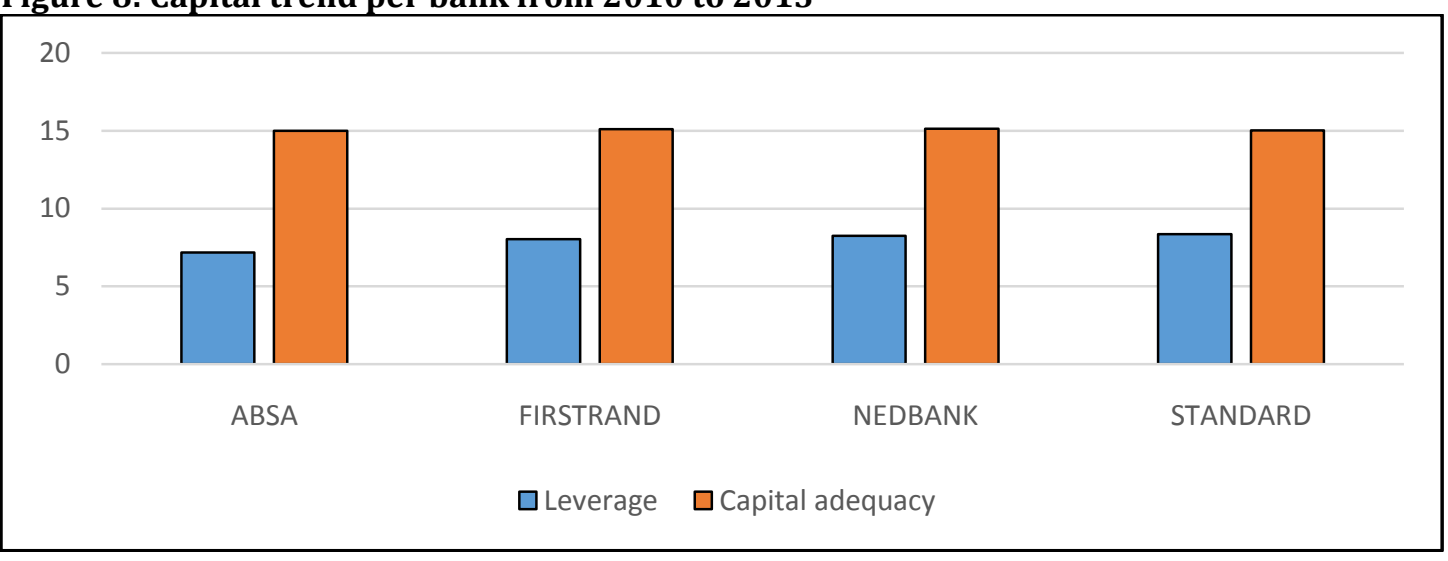

All the above banks show a good leverage situation because the mean of the ratio is $8 \%$. This shows that the bank can pay their liabilities with their assets. The mean of the CAD ratio being more that $10 \%$ shows that South African banks ensure the efficiency and the stability of their system by lowering the risk of insolvency.

\section{Hypothesis testing 1:}

H01: Financial ratios measured by Profitability, liquidity, credit and capital ratios have no statistical significant impact on performances of South African Banks.

HA1: Financial ratios measured by Profitability, liquidity, credit and capital ratios have statistical significant impact on performances of South African Banks.

In this hypothesis, the dependent variable to assess bank performance is Return on Assets ratio. Table 10 shows the correlation matrix between the dependent (ROA) and the independent variables namely profitability, liquidity, credit and capital ratios.

Table 10: Correlation Matrix between variables

\begin{tabular}{llllllllll}
\hline & ROA & ROE & C/I & NLTA & NLDST & IL & NPL & LR & CAD \\
\hline ROA & 1 & 0.96 & -0.80 & 0.80 & -0.61 & -0.52 & -0.99 & 0.94 & 0.59 \\
ROE & 0.96 & 1.00 & -0.81 & 0.79 & -0.49 & -0.72 & -0.95 & 0.82 & 0.78 \\
C/I & -0.80 & -0.81 & 1.00 & -0.31 & 0.03 & 0.40 & 0.73 & -0.69 & -0.61 \\
NLTA & 0.80 & 0.79 & -0.31 & 1.00 & -0.88 & -0.62 & -0.85 & 0.75 & 0.52 \\
NLDST & -0.61 & -0.49 & 0.03 & -0.88 & 1.00 & 0.18 & 0.70 & -0.72 & -0.04 \\
IL & -0.52 & -0.72 & 0.40 & -0.62 & 0.18 & 1.00 & 0.50 & -0.22 & -0.96 \\
\hline
\end{tabular}




\begin{tabular}{llllllllll}
\hline$N P L$ & -0.99 & -0.95 & 0.73 & -0.85 & 0.70 & 0.50 & 1.00 & -0.96 & -0.54 \\
$L R$ & 0.94 & 0.82 & -0.69 & 0.75 & -0.72 & -0.22 & -0.96 & 1.00 & 0.20 \\
$C A D$ & 0.59 & 0.78 & -0.61 & 0.52 & -0.04 & -0.96 & -0.54 & 0.28 & 1 \\
\hline
\end{tabular}

Sources: Computed by the Author. Correlation is significant at $5 \%$ level

From the table 10, there is a strong correlation between Profitability, Liquidity, Credit and Capital ratios that form the overall performance of South African banks. It shows that there is a positive correlation between ROA and ROE, NLTA, LR and CAD while negative correlation with C/I, NLDST, IL and NPL. The result indicates that with the increase in ROE, NLTA, LR, there has been an increase in ROA. The decrease of C/I, NLDST, IL and NPL lead to the increase of ROA.

Table 11: Hypothesis summary

\begin{tabular}{|c|c|c|c|}
\hline Ratios & Mean & P-Value & $\begin{array}{l}\begin{array}{l}\text { Decision on null } \\
\text { hypothesis }\end{array} \\
\end{array}$ \\
\hline ROE & 14.696 & 0.036 & Reject \\
\hline $\mathrm{C} / \mathrm{I}$ & 54.156 & 0.199 & Accept \\
\hline NLTA & 67.883 & 0.196 & Accept \\
\hline NLDST & 89.644 & 0.385 & Accept \\
\hline IL & 1.073 & 0.48 & Accept \\
\hline NPL & 5.585 & 0.005 & Reject \\
\hline LR & 7.955 & 0.057 & Accept \\
\hline CAD & 15.063 & 0.41 & Accept \\
\hline
\end{tabular}

Sources: Computed by the Author. Correlation is significant at $5 \%$ level

At a 5\% significance level, the correlation between ROA and ROE is significant as well as with NPL because the p-values are less than 0.05 as presented in table 11 . Therefore, null hypothesis is rejected. The correlation between bank profitability (ROA) and bank performance variables C/I, NLTA, NLDST, IL, NPL, and LR is insignificant because the p-values are more than 0.05 as presented in table 10 . Therefore, null hypothesis is accepted.

\section{Hypotheses 2:}

HO2: Bank size has no statistical significant impact on performances of South African Banks.

HA2: Bank size has statistical significant impact on performances of South African Banks.

In this study, the volume of assets is used as a proxy of the dependent variables (bank size) and the bank performance variables (financial ratios) as the proxies of bank performance. Table 12 shows the summary statistics of those variables. The resulting correlation coefficient is given in the table 13.

Table 12: summary statistics of variables: Assets and financial ratios

\begin{tabular}{llllll}
\hline & & ABSA & FIRSTRAND & NEDBANK & STANDARD \\
\hline \multirow{3}{*}{ ASSETS } & MEAN & 745925.8 & 812431 & 633639 & 1517051 \\
& SD & 42144.09 & 102426.6 & 51961.41 & 149548.27 \\
ROA & MEAN & 1.0275 & 1.6 & 0.895 & 1.15 \\
& SD & 0.09215 & 0.25152 & 0.181567 & 0.14387 \\
& MEAN & 14.3825 & 19.825 & 10.8 & 13.78 \\
& SD & 1.55087 & 2.01556 & 1.75309 & 0.8539 \\
C/I & MEAN & 55.225 & 52.975 & 56.5 & 51.93 \\
& SD & 1.746186 & 0.71821 & 0.24494 & 15.6785 \\
NLTA & MEAN & 74.9175 & 62.515 & 80.9375 & 53.16 \\
\hline
\end{tabular}




\begin{tabular}{llllll}
\multicolumn{5}{c}{$\begin{array}{c}\text { Journal of Economics and Behavioral Studies (ISSN: 2220-6140) } \\
\text { Vol. 9, No. 2, pp. 6-21, April 2017 }\end{array}$} \\
\hline \hline \multirow{5}{*}{ NLDST } & MEAN & 87.35 & 85.535 & 95.9825 & 89.711 \\
& SD & 2.400694 & 1.062999 & 0.515841 & 1.617426 \\
IL & MEAN & 1.215 & 1.02 & 1.09 & 0.965 \\
& SD & 0.264008 & 0.20199 & 0.149081 & 0.069522 \\
NPL & MEAN & 6.665 & 4.1225 & 7.225 & 4.325 \\
& SD & 0.73 & 0.649635 & 0.431692 & 1.228481 \\
LR & MEAN & 7.17 & 8.035 & 8.2525 & 8.3625 \\
& SD & 0.493559 & 0.495681 & 0.414035 & 0.708725 \\
CAD & MEAN & 15 & 15.1 & 15.125 & 15.025 \\
\hline & SD & 0.439697 & 0.976388 & 0.556028 & 0.914239 \\
\hline
\end{tabular}

Sources: Computed by the Author. Correlation is significant at $5 \%$ level

Pearson correlation is used to find the correlation coefficient relationship between variables at $5 \%$ level of confidence according to the excel software package and the outcomes are presented in Table 13 below.

Table 13: Correlation between bank size and bank performance variables

\begin{tabular}{|c|c|c|c|c|c|c|c|c|c|c|}
\hline & Assets & $R O A$ & $R O E$ & $C / I$ & NLTA & $N L D S T$ & $I L$ & $N P L$ & $L R$ & $C A D$ \\
\hline Assets & 1 & 0.12359 & 0.015862 & -0.8247 & -0.88133 & -0.1707 & -0.68229 & -0.6565 & 0.440924 & -0.4682 \\
\hline ROA & 0.12359 & 1 & 0.966961 & -0.65944 & -0.5774 & -0.76062 & -0.45956 & -0.8277 & 0.113355 & 0.157216 \\
\hline ROE & 0.01586 & 0.966961 & 1 & -0.57454 & -0.47758 & -0.87731 & -0.23304 & -0.729 & -0.14359 & 0.004143 \\
\hline $\mathrm{C} / \mathrm{I}$ & -0.8247 & -0.65944 & -0.57454 & 1 & 0.993332 & 0.601347 & 0.734474 & 0.96043 & -0.33877 & 0.320017 \\
\hline NLTA & $\overline{-} .88133$ & -0.5774 & -0.47758 & 0.993332 & 1 & 0.51476 & 0.767709 & 0.93264 & -0.39924 & 0.326929 \\
\hline NLDST & -0.1707 & -0.76062 & -0.87731 & 0.601347 & 0.51476 & 1 & -0.00505 & 0.63676 & 0.457807 & 0.470562 \\
\hline IL & $-\overline{0.68229}$ & -0.45956 & -0.23304 & 0.734474 & 0.767709 & -0.00505 & 1 & 0.7673 & -0.884 & -0.298 \\
\hline NPL & $\begin{array}{l}- \\
0.65647\end{array}$ & -0.82765 & -0.72901 & 0.960425 & 0.932642 & 0.636755 & 0.7673 & 1 & -0.384 & 0.096556 \\
\hline LR & 0.44092 & 0.113355 & -0.14359 & -0.33877 & -0.39924 & 0.457807 & -0.884 & -0.384 & 1 & 0.573592 \\
\hline CAD & -0.4682 & 0.157216 & 0.004143 & 0.320017 & 0.326929 & 0.470562 & -0.298 & 0.09656 & 0.573592 & 1 \\
\hline
\end{tabular}

Sources: Computed by the Author. Correlation is significant at $5 \%$ level

Table 13 shows a positive and negative relationship between bank size and bank performance. The positive correlation between Assets and ROA with a weak coefficient of 0.12359 means that with a one percent increase of the bank size, there is 1.2359 percent increase in ROA of the bank. According to the above results, bank size is negatively related to C/I, NLTA, NLDST, IL, NPL, CAD ratios.

Table 14: Hypothesis summary

\begin{tabular}{lllll}
\hline Ratios & Mean & P-Value & $\begin{array}{c}\text { Decision on } \\
\text { hypothesis }\end{array}$ & null \\
\hline ROA & 1.169375 & 0.87641 & Accept \\
ROE & 14.696 & 0.984138 & Accept \\
C/I & 54.156 & 0.175299 & Accept \\
NLTA & 67.883 & 0.118665 & Accept \\
NLDST & 89.644 & 0.829302 & Accept \\
IL & 1.073 & 0.31771 & Accept \\
NPL & 5.585 & 0.343527 & Accept \\
LR & 7.955 & 0.559076 & Accept & \\
CAD & 15.063 & 0.531795 & Accept & \\
\hline
\end{tabular}

Sources: Computed by the Author. Correlation is significant at $5 \%$ level 
At a 5\% significance level, the correlation between bank size and bank performance is insignificant because the p-values are more than 0.05 (P-Value $>0.05$ ) as presented in table 14. Therefore, null hypothesis is accepted. Although there is an insignificant relationship between bank size and bank performance, the correlation coefficient can at least explain the link between those variables. The volume of assets represents bank's biggest source of incomes. Therefore, the increase of bank size systematically increases bank profit. South African banking industry is dominated by the four largest banks because of the volume of their assets compared to the other South African banks namely Capitec, Investec Bank, Teba Bank and African bank, all classified as small banks.

\section{Conclusion and Recommendations}

The present study uses Financial Ratios Analysis (FRA) to measure and evaluate South African Banks Performance over a four years period from 2010 to 2013. This report takes into consideration "the big four" South African banks namely Absa, FirstRand, Nedbank and Standard chartered to measure the performance at four performance levels namely Profitability, Liquidity, Credit and Capital performance. Trend analysis during the sample period showed that FirstRand bank was the best achiever, Standard Bank the second achiever followed by Absa and Nedbank. The trend also shows the overall increase in profitability, liquidity, and credit and capital performance during the study period for the all four banks. A correlation analysis between bank profitability and bank performance shows that Return On Assets (ROA) as a key measure of bank profitability had a strong positive and strong negative correlation with all other profitability, liquidity, credit and capital ratios as determinants of bank performance. However, only the relationship between Return on Assets (ROA) and Return on Equity (ROE) as well as Non-performing loans (NPL) appears significant. South African banks should then improve their asset portfolio according to the percentage of Nonperforming loans in order to increase profit and so the overall financial ratios. The results also show insignificant relationship between bank size and bank performance at a degree of significance of $5 \%$ even though the coefficient of correlation shows moderate and strong relationship among them. Despite the statistical insignificant relationship between these variables, correlation coefficient can at least explain the link between them. The volume of assets represents bank's biggest source of incomes. Therefore, the higher the volume of bank' assets the higher the performance of the bank. Ultimately, the four largest South African Banks were profitable during the period from 2010 to 2013 with a good level of liquidity, credit and capital requirements.

Recommendations: Although the four studied South African banks outperformed during the sample period, they should not only rely on the viability of current resources but also rely on new business opportunities regarding the environment changes and the global competition. Banks need to introduce new banking technologies and look for new markets locally and externally. There is also a need to expand on branches and subsidiaries. Such innovations will assist banks to be more competitive and remain large in the South African banking industry and also around the world. Bank managers need to be well-skilled and trained on financial management institutions in order to master bank management in terms of risk and return. The South African Reserve Bank needs to keep sound regulations and supervisory system as during the crisis period to protect the banking industry against recession, failure and any eventual crisis. It is recommended that future research could address and further investigate the financial gap between South African large and small banks. Regarding the pivotal role of regulators in South African context, future researches need to compare the South African Banks' performance with those of other African banks. Future researches should consider both internal and exogenous variables in bank performance analysis. In addition, it is recommended to emphasize on a comparative analysis with other approaches such as Data Envelopment Analysis (DEA) and Regression analysis in order to add value to research findings.

Acknowledgment: This study was conceptualized by Bakam FotsoGenevieve. It was reworked and remixed under the guidance of E.I EDOUN for consideration and publication in your journal. It has never been published in any journal or conference proceedings. 


\section{References}

Absa (Various years). Annual reports. Retrieved from: http://www.absa.co.za/[accessed 20 June 2014]

Adewoye, O. J. \& Omoregie, N. V. (2013). The impact of automatic teller machines on the cost efficiency of Nigeria. Journal of Internet Banking and Commerce, 18(3), 2-21.

Al Karim, R. \& Alam, T. (2013). An evaluation of financial performance of private commercial banks in Bangladesh: Ratio analysis. Journal of Business Studies Quarterly, 5(2), 65-76.

Baten, A. \& Begum, S. (2014). Stochastic frontier model for cost and profit efficiency of Islamic online banks. Journal of Internet Banking and Commerce, 19(1), 1-17.

Bentum, W. (2012). The determinants of profitability of the commercial banks in Ghana during the recent years of global financial crises. Aarshus School of Business, 3, 1-68.

Bodla, B. S. \& Bajaj, R. V. (2010). An analysis of the efficiency of private sector banks in India. The IUP Journal of Bank Management, $9(1 \& 2), 60-82$.

Brigham, E. F. \&Daves, P. R. (2010). Intermediate financial management. Tenth edition. South-Western, Cengage Learning.

Chaffai, M. \& Lassoued, S. (2013). Ownership, technical efficiency and cost of bad loans: Evidence from the Tunisian banking industry. Bankers, Markets \& Investors, 2, 36 -47.

Erasmus, C. \& Makina, D. (2014). An empirical study of bank efficiency in South Africa using the standard and alternative approaches to data envelopment analysis (DEA). Journal of Economics and Behavioral Sciences, 6(4), 310-317.

FirstRand Bank. (Various years). Annual reports. Retrieved from: http://www.firstrand.co.za/[accessed 20 June 2014]

Huang, Y. T., Wen, S. Y. \& Yu, J. (2012). Financial determinants of bank performance in Taiwan. Journal of Economic and Behavioral Studies, 4(12), 691-702.

Investopedia. (2014). Financial Ratios. Retrieved from http://www.investopedia.com/ask/answers/. [Accessed 20 June 2014]

Jagwani, B. (2012). Efficiency measurement in the Indian banking industry: An application of data envelopment analysis. Vision, 16(4), 315-331.

Jamil, S. G. \& Sahar, S. N. (2013). Comparative analysis of four private sector banks as per CAMEL rating. Business perspective and Research, 2, 31-46.

Kristo, S. (2012). Efficiency of the Albanian banking system: Traditional approach and stochastic frontier analysis. International Journal of Economic Sciences and Applied Research, 6(3), 61-78.

Kumbirai, M. \& Robert, W. (2010). A financial ratio analysis of commercial bank performance in South Africa. African Review of Economics and Finance, 2(1), 30-53.

Maimbo, M. S. (2002). Explaining bank regulatory failure in Zambia. Journal of International Development, 14, 229-248.

Mlambo, K. \& Ncube, M. (2011). Competition and efficiency in the banking sector in South Africa. African Development Review, 23(1), 4-15.

Monea, M. (2011). Analysis of incomes, expenses and profitability in banks. Annals of the University of Petroşani Economics, 11(4), 199-206.

Narjess, B., Cosset, J., Klaus F. \& Omrane, G. (2005). Privatization and bank performance in developing countries. Journal of Banking \& Finance, 29(8), 2015- 2041.

Ncube, M. (2009). Efficiency of the Banking Sector in South Africa', paper presented at the Fourth African Economic Conference 2009 on Fostering Development in an Era of Financial and Economic Crises, 11-13 November 2009, Addis Ababa, Ethiopia.

Nedbank bank. (Various years). Annual reports. Retrieved from: http://www.nedbank.co.za/[accessed 20 June 2014]

Nguyen, K. M., Giang, T. L. \& Nguyen, V. H. (2013). Efficiency and super-efficiency of commercial banks in Vietnam: Performances and determinants. Asia-Pacific Journal of Operational Research, 30(1), 1-19.

Oberholzer, M. \& Van Der Westhuisen, G. (2010). The relationship between economic value added and data envelopment analysis based on financial statements: Empirical evidence of South African listed banks. Management Dynamics, 19(3), 29-41.

Oluitan, R. (2014). Bank efficiency in Africa. The Journal of Developing Areas, 48(2), 205-222.

Paradi, J. C., Sandra, A. V. \& Zhu, H. (2010). Adjusting for cultural differences, a new DEA model applied to a merged bank. Journal of Productivity Analysis, 33, 109-123. 


\section{Journal of Economics and Behavioral Studies (ISSN: 2220-6140)}

Vol. 9, No. 2, pp. 6-21, April 2017

Salkind, N. (2012). Exploring research. 8th edition. Upper Saddle River, N.J.: Pearson International.

Saunders, A. \& Cornett, M. M. (2011). Financial institutions management: a risk management approach $\left(7^{\text {th }}\right.$ edition). McGraw-Hill.

Shamsuddin, A. \& Xiang, D. (2012). Does bank efficiency matter? Market value relevance of bank efficiency in Australia. Applied Economics, 44, 3563-3572.

South African Reserve Bank. (2014). Publication and Notices Review, Pretoria: South African Reserve Bank. [Online] Available on http://www.reservebank.co.za/[accessed 20 June 2014]

Standard bank. (Various years). Annual reports. Retrieved from: http://www.standardbank.co.za/[accessed 20 June 2014].

Tesfaye, B. L. (2014). The determinants of Ethiopian Commercial Banks performance. European Journal of Business and Management, 6(14), 52-63

Van der Westhuizen, G. (2013). Bank productivity and sources of efficiency change: A case of the four largest banks in South Africa. International Business and Economics Research Journal, 12(2), 127-138.

Van der Westhuizen, G. (2014). Bank efficiency and financial ratios: rating the performance of the four largest South African banks. Journal of Applied Business Research, 30(1), 93-104.

Van Heerden, C. \& Heymans, A. (2013). A fundamental evaluation of the Top five South African banks after the Financial Crisis. Journal of economic and financial sciences, 6(3), 729-760.

Zago, A. \& Dongili, P. (2011). Credit quality and technical efficiency in banking. Journal of Empirical Economics, 40, 537-558. 